\title{
The Importance of Regional Trails for the Viability of the Brazilian Long Trails Network
}

\author{
Michel Tadeu R. N. de Omena \\ Michel Bregolin
}

${ }^{\text {I }} \mathrm{PhD}$ program in Ecology, Federal University of Santa Catarina (UFSC), Florianópolis, Santa Catarina, Brazil.

II Caxias do Sul University (UCS), Caxias do Sul, Rio Grande do Sul, Brazil.

\begin{abstract}
Accelerated urbanization has stimulated tourism in natural areas and the search for a reconnection between man and nature. In that context, this article narrates the implementation of the Brazilian Trails System (RBT) based on the monitoring of the Regional Trail Caminho das Araucárias activities and the analysis of official documents and data available in social media. We evaluated the RBT's potential to contribute to environmental conservation, landscape connection, tourism promotion and well-being through open-air recreation. In this study, we found that 1.600 kilometers of new trails were created in two years, and that there has been a growth of volunteer work and of integration among Protected Area managers. Lastly, the study highlights the importance of regional trails in enabling the RBT and its valuable contribution to the conservation of protected areas and the generation of employment and local income, based on the good practices of similar international initiatives.
\end{abstract}

Keywords: Trails; Conservation; Tourism; Protected Areas; Brazilian Trails System; Araucárias Way.

São Paulo. Vol. 23, 2020

Original Article

DOI: http://dx.doi.org/10.1590/1809-4422asoc20190053r2vu2020L5AO 


\section{Introduction}

In the course of the 20th century a process of demographic and urban-industrial concentration began leading to the creation of highly densified metropolitan areas (MATOS; BAENINGER, 2004). Concomitantly, contact with nature in those areas became limited to a few small spaces that ended by being highly overcrowded in the leisure periods of the respective communities (LOBODA; DEANGELIS, 2005; COHEN et al., 2005).

Today, it can be seen that the more urban agglomerations grow the greater the rate of people leaving them for vacation trips (BENI, 2007). An indication of that phenomenon in Brazil is the intensification of Federal Protected Areas visitation which jumped from 1.9 million visitors in 2000 to 12.4 million in 2018 (SOUZA; SIMÕES, 2018; ICMBIO, 2019a). In the period from 2012 to 2018, that growth was even more remarkable, registering an increase of 100\% (ICMBIO, 2019a).

That increased demand for the recreational use of Protected Areas (PA) on the part of the public has stimulated a change in the PA management paradigm in Brazil. It has meant that the understanding is no longer merely to protect and preserve but to recognize that their orderly, public use for leisure purposes is an objective just as important as conservation CASTRO, 2018).

That new understanding comes close to the one adopted in the United States in 1872 when the Yellowstone National Park was created, considered to be the first place in the world to adopt the modern concept of Protected Areas (EAGLES; HAYNES; MCCOOL, 2002). According to that concept, protected areas are open spaces that enhance the quality of life of urban populations by enabling them to engage in physical activities and the contemplation of nature (EAGLES; HAYNES; MCCOOL, 2002).

In line with that concept, according to the statistics of the National Park Service (NPS, 2019), the United States protected natural areas system - with a territorial dimension equivalent to that of the Brazilian system (MENEZES, 2014) - received a total of 331 million visitors in 2017, a figure 30 times greater than the numbers visiting the Brazilian system in the same year. As a result of that visitor flow, the United States registered spending of 8 billion dollars in the areas of hotel accommodation, restaurants, tourism services, gasoline stations and others (STATISTA, 2018).

That data is an indication of how expanding the public use of Brazilian protected areas could convert them into an economic development alternative and an incentive to draw the population closer to nature. Incrementing their use could endow the protected areas with greater visibility and contribute by alerting society to the risks associated with reducing the protected areas or altering their category from one of greater protection to lesser protection or even removing protection altogether (CORREIA et al., 2018).

Against that background, nature trails stand out as a different option for Brazil, especially bearing in mind, on the one hand, the restricted financial resources allocated for administering PAs (MEDEIROS et al., 2011) and on the other, the low cost involved, the simple infrastructure requirements and the modest level of physical exertion that walking demands from those that practice it. In that light, the implantation of a national trails network presents itself as a viable instrument for providing society with access to those areas (MENEZES, 2014) 
Trails can encourage people to make contact with nature. A good example of that is in France where, in 2017, the National Ramblers Federation (Fédération Française de la Randonnée Pédestre) registered 250 thousand members and 20 thousand volunteers who, together, managed to maintain 180 thousand kilometers of trails (FFRP, 2017). Along those trails, 15 million people walk every year; that is roughly $22 \%$ of the French population (INSEE, 2018).

In addition to favoring access to natural areas, the trails can also offer an alternative way to achieve other objectives such as fostering the health of the population (MERRIAM et al., 2017) and fostering the development of the local economy (PLTA, 2011).

In regard to the health aspect, it should be borne in mind that public parks are an important element in the construction of a healthy living environment so that making them available constitutes a proactive and preventive public health intervention (ARENA et al., 2017). A similar affirmation is made by Merriam and collaborators (2017) who state that parks and trails make a holistic contribution to human health insofar as they provide opportunities for people to do physical exercise, reduce stress, interact socially and, indirectly, support environmental sustainability.

As mentioned previously, in addition to contributing to people's health the trails stimulate local economies (PLTA, 2011). In the case of the Virginia Creeper Trail in the United States, for example, it was found that the economic impacts of visitors' spending on the two municipalities bordering the trail was to the order of 1.6 million dollars in 2003 (BOWKER; BERGSTROM; GILL, 2007). Another outstanding case is the province of Huesca in Spain where the practice of hiking along trails was responsible for revenue from tourism of 32 million Euros in 2003 (GALLEGOS, 2007).

Another example of economic impact associated with trails stems from the events that promote them. In France, the Jasseries Ramble (Randonnée des Jasseries) in 2015 generated an impact of 36 Euros in the local economy for every Euro that was invested in the event (VALLON PONT D'ARC, 2016; FFRP, 2017).

Trail implantation in Brazil is a recent process and as yet there are no studies on the economic impact of trips motivated by the practice of hiking. However, Souza and Simões (2018) insist that it is possible to discern their potential when one considers that for every real invested in Brazilian PAs in 2017, Brazilian society received seven reals in economic benefits.

Considering that walking tourism represents an important tool for sustainable tourism and guarantees the conservation of the cultural and natural heritage (KASTENHOLZ; RODRIGUES, 2017) and based on the positive results obtained from the implantation of the Transcarioca Trail in Rio de Janeiro, (MENEZES, 2015; O GLOBO, 2017) efforts were made to create a Brazilian long trails network (Rede Brasileira de Trilhas de Longo Curso - RBT) which culminated in the official formalization of the National Network of Long Course and Connectivity Trails (Rede Nacional de Trilhas de Longo Curso e Conectividade - RedeTrilhas) by means of a joint edict published by the Ministries of the Environment and of Tourism (BRASIL, 2018a). That was a priority regulatory action for the country to rapidly take full advantage of its potential for nature tourism which the World Travel and Tourism Council has declared to be the greatest on the planet (WTTC, 2018). 
With an area of $8,515,767 \mathrm{~km}^{2}$ (IBGE, 2012) the equivalent of almost $50 \%$ of South America (FIGUEIREDO, 2010), Brazil has the conditions to develop a broad tourism offer orientated towards hiking and rambling. That is easily justified by considering that France, with a land area roughly 17 times smaller, has 180,000 km of trails (FFRP, 2017; INSEE, 2018).

It is also worth noting that, while in other countries protected natural areas are intimately related to National Parks or wilderness areas, in Brazil the term also embraces indigenous lands and quilombolas. That is why, altogether, Brazil's protected areas extend over $30.2 \%$ of its land area (EMBRAPA, 2018). Many of those areas have good potential for receiving trails that can encourage the populations in the surrounding areas and the visitors to get involved in conservation; enhance the value of local cultural aspects; and generate employment and income (GALLEGOS, 2007; BREVES; MENEZES, 2018).

As walking is a low-impact, indirect use activity, the implantation of trails for hikers would seem to be suitable even in protected natural areas created strictly for nature conservation referred to in the Brazilian legislations as Unidades de Conservação (Conservation Units) in the terms of Act n⿳9 9.985, dated July 18th, 2000, which established the National Protected Areas System (Sistema Nacional de Unidades de Conservação da Natureza - SNUC) (BRASIL, 2000).

An analysis of the respective law shows that a priori such infrastructure could be installed without any great problems even in certain categories of Protected Areas of the Integral Protection group which have the most restrictions and require that use can only be indirect. The category 'National Parks' is one such and susceptible to receiving this kind of action insofar as its objectives are linked to the proposal for the development of sustainable tourism and open air recreation activities (BRASIL, 2000) and in the case of the Sustainable Use category there are no restrictions on this kind of implantation at all (BRASIL, 2000).

The elements presented above show that Brazil has tremendous potential for developing tourism based on trail walking; one that could involve as many as 2 million people a year according to Ministry of Tourism estimates (Brasil, 2018b). However to take full advantage of that potential and maintain alignment with the nature conservation requirements and the requirements of social and economic development, it is essential to verify how the implantation of that network is being effectuated.

By doing that it will become possible to identify in advance situations that could place its effectuation at risk and take timely and suitable steps to mitigate or suppress them. It will also be feasible to identify actions that could be replicated to boost the network, based on successful experiences in other countries.

To that end this article established the following objectives: a) describe the present situation of the RBT; b) describe situations associated to its implantation as exemplified by the regional trail the Araucárias Way; c) identify aspects related to its implantation that require attention or improvement; d) identify measures adopted in similar situations in other countries that could be incorporated to the Brazilian network to reduce implantation risks and boost benefits. 


\section{Methodology}

This research can best be described as qualitative and exploratory-descriptive (GIL, 2011). Its qualitative character is associated to the data gathering instruments and the nature of the analyzed data. Again according to Gil (2011), the research is exploratory insofar as it adopts a flexible approach in the research procedures to achieve its objective, in view of the very limited scientific production on the theme in Brazil. Furthermore, it is also descriptive because it narrates the process of implantation of the RBT.

In regard to the data gathering procedures, they consisted of participative observation of the activities of the group responsible for implanting the regional trail Caminho das Araucárias (The Araucarias Way), which integrates the coastal corridor of the RBT, and of consulting sources accessible on the internet and documents related to long-distance trails.

On the Internet, data was collected from the official pages of national and international long-distance trail systems, from newspaper articles, and from thematic groups in social media such as Facebook, Youtube and Wikiparques. The documental data was obtained from documents edited by the Chico Mendes Institute for Biodiversity (ICMBio), the Ministry of the Environment and the Ministry of Tourism, designed to orientate and regulate the RBT and from the minutes of the meetings of the administrative groups of the RBT and of the Araucarias Way.

The collected material was subjected to content analysis including a posteriori categories, that is categories that emerged from the corpus of the collected data (BARDIN, 2000), a situation coherent with the exploratory nature of the research and with the limited availability of relevant data in Brazil. Based on all of that, it was possible to obtain the results that will now be presented and discussed.

\section{Results}

\section{The Brazilian Long Trails Network}

The first act creating a long trail in Brazil took place in Rio de Janeiro in 1999 with the implantation of the Transcarioca Trail (MENEZES, 2015; O GLOBO, 2017). Since then, that trail has expanded and currently it is 180 kilometers long; an extension achieved by means of a process that simultaneously stimulated partnership arrangements with Protected Areas, articulations of various spheres of government and the involvement of an ever increasing number of volunteers (TRILHA TRANSCARIOCA, 2018).

Supported by the positive results of Transcarioca Trail, recognized in 2017 as a public equipment of the municipality of Rio de Janeiro and the longest urban trail in South America (O GLOBO, 2017), the Gerneral Use Coordinating of Public Use of the ICMBio created the RBT to encourage the reproduction of that model in other regions of the country (Brasil, 2018c).

One of the RBT's most important features is that it allows for the participation of civil society partners such as mountain climbing and boy scout groups all of whom work 
voluntarily. It can also count on the engagement of the environmental entities of state and municipal governments.

To stimulate the mobilization of that network of partners, the ICMBio has organized capacity building workshops for entities and volunteers in various Brazilian states, ever since 2017 (MENEZES, 2017; MENEGASSI, 2017b). During those workshops the RBT is presented and guidance is offered regarding the planning and sign installation of the trail trajectories.

Due to the network's evident potential for incrementing the national tourism offer and promoting domestic tourism, in October 2018, the RBT began to receive formal support from the Ministry of Tourism with the establishment of a term of cooperation (ICMBIO, 2018; BRASIL, 2018b). It also received recognition as one of the initiatives contemplated by the 2018 National Tourism Award (MENEGASSI, 2018).

\section{Trails as PA connectors}

The ICMBio and its partners have been working to ensure that in addition to their pro-tourism aspect, the trails serve as connectors of landscapes and foster the creation of ecological corridors among different PAs. Such corridors play an important role in nature conservation insofar as they avoid the isolation of wild populations and the associated risk of extinction. That importance of the trails for landscape connectivity was officially acknowledged by Edict n⿳⺈ 75, dated March 26, 2018 (BRASIL, 2018d), which instituted the National Landscape Connectivity Program (Conecta) of the Ministry of the Environment (MMA).

Guided by the terms of the program a broad set of actors has been working to implant new trails, implanting signs with the same pattern of black and yellow footprints (Figure 1) in accordance with orientation of the Manual with recommendations for sign implantation edited by the ICMBio (BRASIL, 2018c) and available in the internet for download.

Figure 1 -Symbol of the Brazilian Long Trails Network

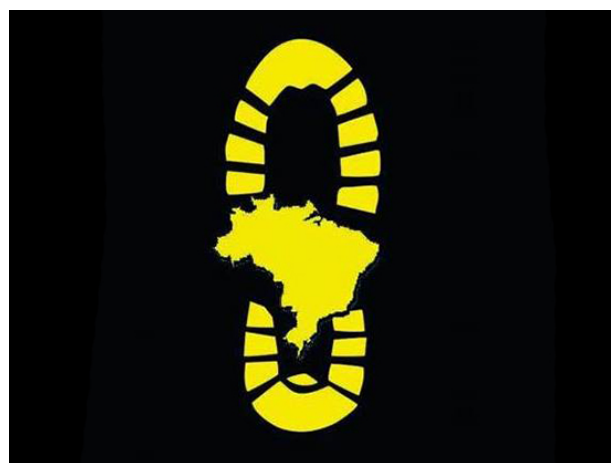

Source: Breves and Menezes (2018). 
Breves and Menezes (2018) report that in addition to the Transcarioca Trail the RBT was inspired on the lines of the National Trails System in the United States and the European equivalent, the European long-distance paths. In the case of the latter system, according to the European Ramblers Association (ERA, 2018), each of the 12 so-called E-paths (E1 to E12) is made up of shorter national or regional stretches that were created to boost local trade and tourism services. The same premise was adopted by the RBT and so it is made up of a set of regional trails composing each long corridor (MENEGASSI, 2017b).

Furthermore, the final stretches of the regional trails coincide with the beginning of the next ones so that the traveler can hike for variable periods according to the leisure or vacation time he or she has available (BREVES; MENEZES, 2018). That is a way to stimulate the involvement of the communities in the surrounding areas in the maintenance and development of the trails. It is in that sense that the RBT is being implanted jointly by civil society and government entities (BREVES; MENEZES, 2018).

To encourage their appropriation by communities of each region, the standard signs incorporate visual elements of local significance. Figure 2 shows an example of that in the sign destined for the Araucárias Way in which the footprint is a reference to the Puma (Puma concolor), a species that symbolizes the local fauna. In other stretches of the same trail the feature represented in the sign is the Brazilian pine species Araucaria (Araucaria angustifolia), an important element in the composition of the landscape traversed by the regional trail.

Figure 2 - Implantation of a standard RBT trail sign along the Araucárias Way during a capacity building workshop for volunteers held in the São Francisco de Paula National Forest

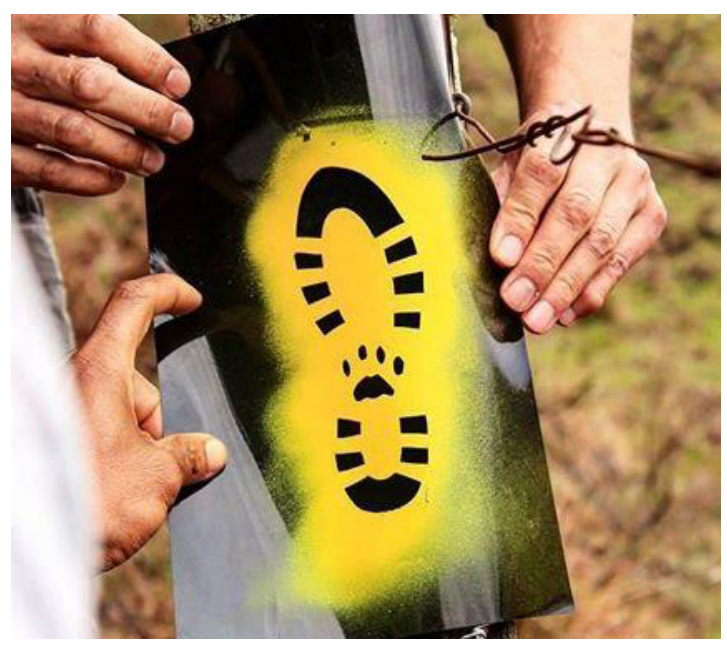

Source: Daniel Spiazzi (2019a). 


\section{The Trails of the Brazilian Network}

According to ICMBio (2018b) data, by October of 2018 1,900 km of trails were ready, distributed in a mosaic of four main long-distance itineraries (Table 1). Up until now no regulation of the nomenclature has been established to determine the names that should be used in each case and accordingly a variety of terms adopted by local actors involved in the implantation of each local trail are in use such as circuit, way, corridor, trail, route or passage. Nevertheless, the most commonly used terms are corridor or way for the main itineraries which are composed by sets of regional or local ones (ICMBIO, 2018).

Table 1 - Main Itineraries of the Brazilian Long Trails Network

\begin{tabular}{|l|l|}
\hline \multicolumn{1}{|c|}{ Name } & \multicolumn{1}{c|}{ Description } \\
\hline $\begin{array}{l}\text { Coastal Corridor } \\
\text { (Corredor Litorâneo) }\end{array}$ & $\begin{array}{l}\text { Will connect the municipalities of Oiapoque and Chuí, located } \\
\text { in the extreme north and extreme south of the Brazilian coast } \\
\text { respectively. }\end{array}$ \\
\hline $\begin{array}{l}\text { The Goyazes Way } \\
\text { (Caminho dos } \\
\text { Goyazes) }\end{array}$ & $\begin{array}{l}\text { Will connect the historical city of Goiás Velho with the Chapada } \\
\text { dos Veadeiros National Park, both in the state of Goiás. Planned to } \\
\text { pass through the Federal District as well. }\end{array}$ \\
\hline $\begin{array}{l}\text { Colonial Ways } \\
\text { (Caminhos Coloniais) }\end{array}$ & $\begin{array}{l}\text { Historical routes used in Brazil's imperial and colonial periods } \\
\text { located between the coast of the state of Rio de Janeiro and the } \\
\text { with the Goyazes Way. }\end{array}$ \\
\hline $\begin{array}{l}\text { The Peabiru Ways } \\
\text { (Caminhos do Peabiru) }\end{array}$ & Will connect the Iguaçu National Park to the Paraná coast. \\
\hline
\end{tabular}

Source: Elaborated by the authors (2019).

Among the totally or partially implanted regional itineraries that make up the Coastal Corridor are the Rota dos Faróis (Lighthouses Route), the Travessia do Tabuleiro (the Tabuleiro Passage), the Rota da Baleia Franca (Right Whale Route), the Transmantiqueira, the Trilha Transcarioca (Transcarioca Trail), the Rota Darwin (Darwin Route), the Caminhos da Serra do Mar (Serra do Mar Ways), the Travessia do Caparaó (Caparaó Passage), the Rota do Descobrimento (Discovery Route), the Rota das Emoções (Emotions Route), the Rota do Guarumã (Guarumã Route), the Trilha do Amapá (Amapa Route), Rota da Ilha de Santa Catarina (Santa Catarina Island Route) and the Caminho das Araucárias (Araucarias Way). 
The Caminho de Cora Coralina (Cora Coralina Way), the Trilha Missão Cruls (Cruls Mission Trail) and the Travessia das Sete Quedas (Seven Falls Passage) are components of the Caminho dos Goyazes (Goyazes Way). In turn the regional trails of the Peabiru Way reproduce part of the trajectories from the Atlantic Ocean to the Andes and the Pacific Ocean and an outstanding feature aspect of that way is that the stretch located in the National Araucarias Park in Santa Catarina already has all the signs installed.

In turn the Colonial Ways encompass the Transcarioca Trail, part of the Serra do Mar Ways as well as the Transpinhaço Trail, a route near to the city of Belo Horizonte in Minas Gerais situated between the Serra do Cipó National Park and the municipality of Diamantina, all in that same state.

There are other trajectories apart from those above where the same standardized RBT signs have been installed but without being part of a longer corridor and others that are still at the planning stage. An example of the former case is the Chico Mendes Extractive Reserve Trail in the state of Acre (MENEGASSI, 2017a), and of the latter, the Velho Chico Trail which is intended to extend roughly $2,700 \mathrm{~km}$ from the source of the São Francisco River (known as the Velho Chico) to its mouth. Those examples show the great potential of the RBT for connecting Brazilian PAs and landscapes in different biomes. (Figure 3).

\section{Figure 3 - Map illustrating the Brazilian Long Trails Network}

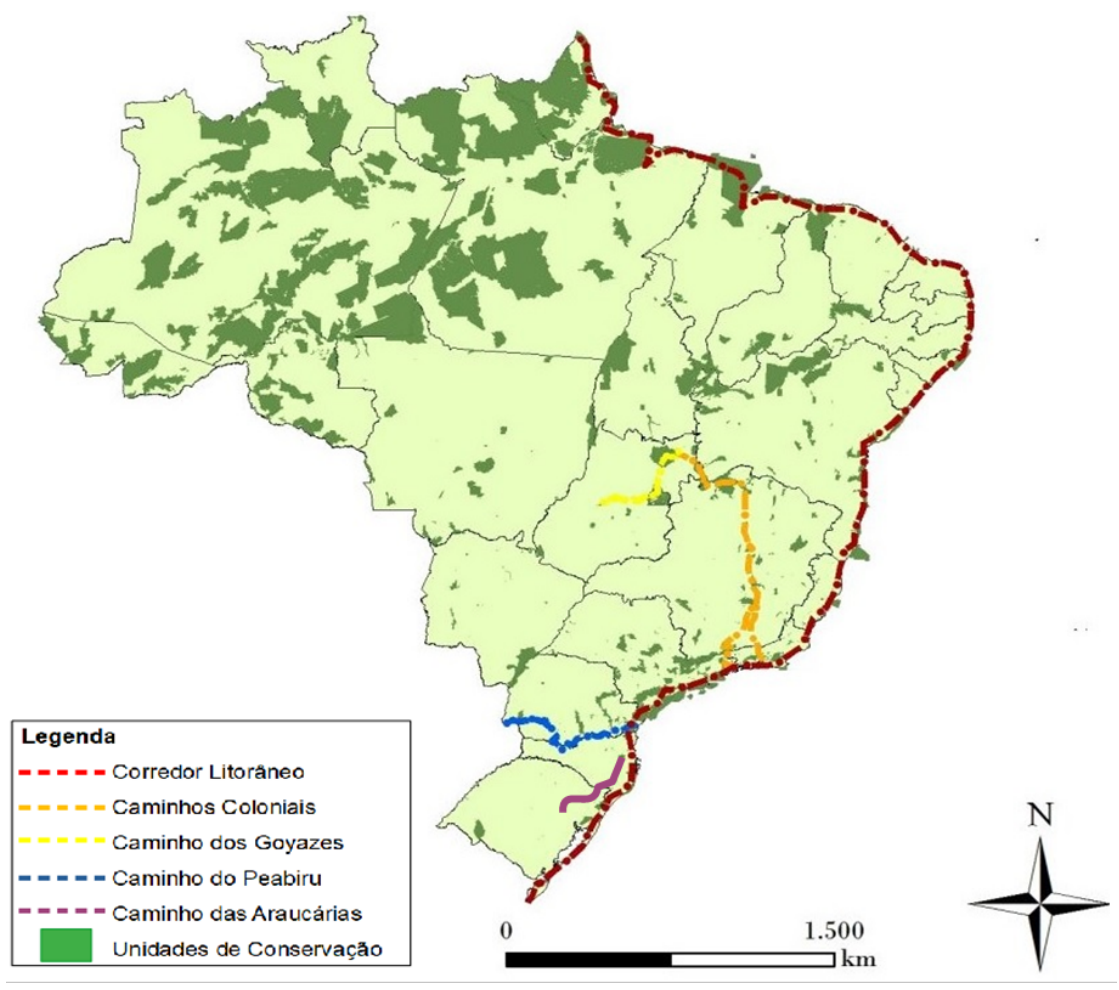

Source: Adapted by the authors from Breves and Menezes (2018). 
Legend

\begin{tabular}{|l|l|l|l|}
\hline Corredor Litorâneo & $\begin{array}{l}\text { Coastal Cor- } \\
\text { ridor }\end{array}$ & Caminho do Peabiru & Peabiru Way \\
\hline Caminhos Coloniais & Colonial Ways & Caminho das Araucárias & Araucarias Way \\
\hline Caminho dos Goyazes & Goyazes Way & Unidades de Conservação & Protected Areas \\
\hline
\end{tabular}

Today, the Brazilian Trails Network reaches 164 private and public PAs, the latter in all spheres of government administration, in 17 states and the Federal District and it has more than 2,000 km with signs already installed and another 2,500 km in which the process of sign installation is in course (WIKILOC, 2019; RBT, 2019).

Making the RBT feasible through the implantation of regional trails: evidence from the Araucarias Way.

The rapid implantation of the RBT is only possible because of the strong adherence of civil society. Part of the evidence for that affirmation consists of elements that are perceptible but lack a reference frame for measuring them, such as the increasingly frequent mention of the theme identified in Google, considered to be the leading search site in the country (STATCOUNTER GLOBAL STATS, 2019), the statistical summary of the number of videos on the subject that have recently become available on Youtube (YOU TUBE, 2019), and the introduction of trails connected to the RBT in specialized Apps such as Wikiloc and Passaporte para Trilhas (Trails Passport) (WIKILOC, 2019; SÃO PAULO, 2018).

There are other data that can be measured and they indicate the same tendency. The main one is the increase in the number of kilometers of trail already using the standard RBT trail signs. In 2016 there were 350 kilometers, in 2018 that had gone to 1,900 (ICMBio, 2018b) and by August 2019 there were over 2,000 kilometers with them implanted (RBT, 2019).

In addition there has been an increase of around $62 \%$ in the number of followers of the RBT's official page on Facebook. While in October 2018 there were 2,581 followers, by September 2019, there were 4,184 (FACEBOOK, 2019).

It can also be imagined that if the data searches were undertaken with the names of the regional stretches those numbers would be significantly larger because, in those stretches, there is a constant process in course of joint sign implantation efforts as exemplified by the announcements of such efforts for the Transmantiqueira Trail (MENEGASSI, 2019) and the Araucarias Way (CAMINHO DAS ARAUCÁRIAS, 2019b).

Thus it is possible to delineate some important situations related to the feasibility of RBT implantation based on regional trails. In the case of the Araucarias Way (Figure 4) the notable feature is the increase in the number of inscriptions of volunteers wishing to participate in sign installation in the São Joaquim National Park: from 24 in 2018 to over 200 in 2019 (ICMBIO, 2019b). Another aspect worth noting is the rapid expansion of the trail signing from $9 \mathrm{~km}$ during the first workshop in the region in September 2017 


\section{to $170 \mathrm{~km}$ in September 2019 (CAMINHO DAS ARAUCÁRIAS, 2019b).}

Figure 4 - Map showing the Araucarias Way
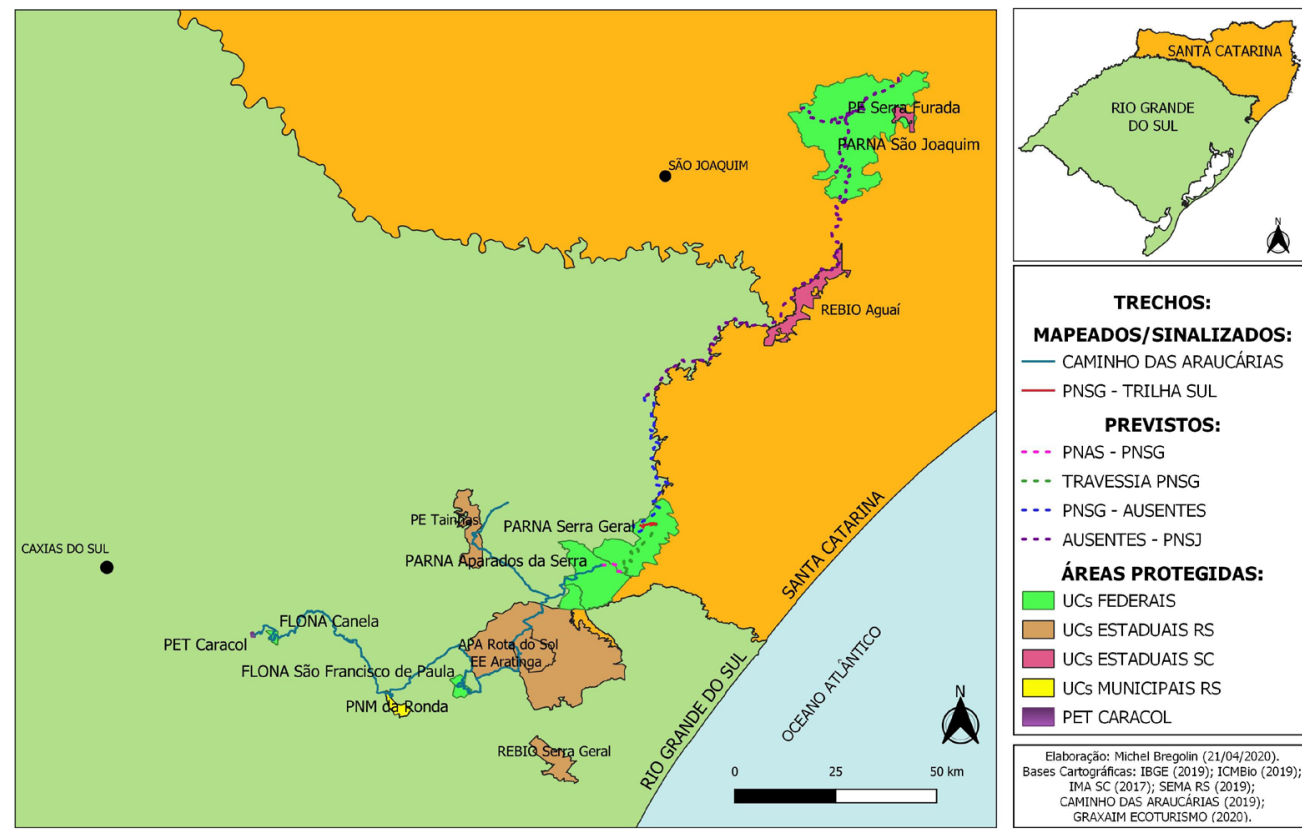

TRECHOS:

MAPEADOS/SINALIZADOS:

- CAMINHO DAS ARAUCÁRIAS

- PNSG - TRILHA SUL

PREVISTOS:

- - PNAS - PNSG

-. TRAVESSIA PNSG

-. - PNSG - AUSENTES

- - AUSENTES - PNS]

\section{ÁREAS PROTEGIDAS:}

UCS FEDERAIS

$\square$ UCS ESTADUAIS RS

$\square$ UCS ESTADUAIS SC

$\square$ UCS MUNICIPAIS RS

PET CARACOL

Elaboraçăo: Michel Bregolin (21/04/2020).
Bases Cartográficas: IBGE (2019); ICMBio (2019); IMA SC (2017); SEMA RS (2019); CAMINHO DAS ARAUCARIAS (2019;

Source: Elaborated by the authors (2020).

Legend

\begin{tabular}{|l|l|l|l|}
\hline $\begin{array}{l}\text { Trechos } \\
\text { Mapeados/Sinalizados }\end{array}$ & $\begin{array}{l}\text { Stretches } \\
\text { Mapped/Signed }\end{array}$ & PARNA & National Park \\
\hline SC & Santa Catarina State & RS & Rio Grande do Sul State \\
\hline Previstos & Planned & PET & State Park \\
\hline Áreas Protegidas & Protected Areas (PAs) & FLONA & National Forest \\
\hline UCs Federais & Federal PAs & EE & Ecological Station \\
\hline UCs Estaduais -RS & State PAs & APA & $\begin{array}{l}\text { Environmental Protected } \\
\text { Area }\end{array}$ \\
\hline UC Estadual-SC & State PA -SC & & Biological Reserve \\
\hline UCs Municipais -RS & Municipal PAs -RS & REBIO & Municipal Nature Park \\
\hline PET Caracol & Caracol State Park & PNM & \\
\hline
\end{tabular}

Currently this regional trail is concentrating on planning, accompanying the work of volunteers and incorporating stretches of other PAs and the trails in their sur- 
roundings, adopting a new approach to ensure a more constant and orderly growth. In addition to the greater number of volunteers and the increased extension of trails with signs implanted, it is worth noting that, in the last two years, six tourism operators have incorporated the Araucarias Way as a new tourism product in the region (CAMINHO DAS ARAUCÁRIAS, 2019b).

All the information presented above is evidence of the progress achieved in the implantation of the RBT and the Araucarias Way in the respective period. Furthermore, an outstanding qualitative result obtained is the adherence to, and participation in the Araucarias way of various Federal, State and Municipal PAs in the states of Santa Catarina and Rio Grande do Sul. They are, in the federal sphere, the Aparados da Serra, Serra Geral and São Joaquim National Parks and the Canela and São Francisco de Paula National Forests; in the state sphere, Tainhas State Park, the Rota do Sol Protected Area, the Aratinga Ecological Station, Aguaí Biological Reserve and the Serra Furada State Park, and there are also the Tourism State Park in Caracol, Rio Grande do Sul, and the municipal PA of Ronda in São Francisco de Paula, Rio Grande do Sul (CAMINHO DAS ARAUCÁRIAS, 2019a).

\section{Discussion}

According to Jepson and collaborators (2017), PAs generate important assets in various categories. They can be: biophysical (fauna and flora conservation), infrastructural (access roads, public services, visitation infrastructure), cultural (maintenance of traditional knowledge), institutional (regulations) or human (guides, park guards, researchers, etc.).

The analysis of the data on RBT implantation reveals promising prospects indicating that the areas can generate assets for society. Among the elements justifying that interpretation are the growing engagement of volunteers in the sign implantation process, the increase in the quantity and extension of the trails with signs installed in Protected Areas and in their surroundings and the increase in the availability of tourism products based on trails offered by regional tourism operators (CAMINHO DAS ARAUCÁRIAS, 2019b). Another outstanding feature has been the greater rapport not only among managers of PAs administered by different spheres of government but also between PA administrations and civil society.

The dynamic process of volunteer participation and engagement shows that the strategy of making the RBT feasible through the construction of regional trails with the involvement of civil society seems to be a valid decision according to what the Araucarias Way data reveals. However that implantation is fairly recent and has taken place in a decentralized way, lacking a greater degree of organization, although there is already a management committee in existence in the Ministry of the Environment for the RBT, because it is part of the previously mentioned landscape connectivity program (BRASIL, 2018d).

The creation of a centralizing agency could improve the communication among partner organizations, standardize monitoring activities, improve planning and identifica- 
tion and rapidly correct any operational problems that appear. Once it has been instituted, precision metrics could be established making it possible to measure how much of the implantation effort is public and how much is private thereby helping to verify whether the RBT has effectively become a vector of civil society involvement and engagement in supporting and conserving PAs or not.

That accompaniment would also provide an opportunity to precociously identify problems it will have to address. Even though it has obtained positive results so far, it is impossible to ignore the fact that in the other countries already occurred negative situations that decrease the favorable results. In that respect, identification of potential inadequate situations for the RBT and the recognition of good practices and measures successfully adopted by other countries would make it possible to obtain greater security in the quest for positive results.

As for the question of organizing civil society's growing participation in the RBT, Chile's experience can serve as a good reference because its project Sendero de Chile (Chile Trail) experienced a series of situations involving volunteers in the course of its existence. That is why ever since the year 2000 it has changed its emphasis from the implantation of trails, to concentrate, instead, on promoting the hiking activity. Furthermore, the project set up a foundation to handle the financial side and ensure its continuity (FUNDACIÓN SENDERO DE CHILE, 2018).

Another case worth studying as a reference is the 3,524 kilometer-long Appalachian Trail running from north to south in the United States. That trail has accumulated a lot of experience in administering a long-distance trail in partnership arrangements with civil society and government bodies. Along that trail there are various stretches that are administered by clubs of hiking and walking enthusiasts and others by non-profit organizations, all of them organized under the umbrella organization of the Appalachian Trail Conservancy (MCKINLEY et al., 2019).

In regard to nature conservation, even with the RBT showing signs of being a positive contribution so far, it is nevertheless wise to remember that human activities in natural environments usually cause negative impacts, however slight the harm may seem (PICKERING; NORMAN, 2017). That is why it is important to underscore that the balance of negative impacts of the activity against positive ones must always favor the side of conservation.

In the case of trails, for example, it must be made clear that invasive exotic species can take advantage of such trails to invade natural wild areas (MACIEL; BITENCOURT; SILES, 2011; XIE, 2018) and also that the trails can affect the local fauna and flora in a variety of ways (SOULLARD, 2017).

Another aspect to accompany is the possibility of an inadequate development of infrastructure in the trails and the surrounding area that receive the trail users, especially in those public and private spaces that lack proper planning and management instruments (RUSCHMANN, 1997). Should that occur it could lead to the de-characterization of the original beauty of the locations (PLOG, 2002) and the destruction of fragile resources by disorderly growth; a situation that Krippendorf (1977) warned about as far back as 1970 when he wondered whether "tourism might destroy the very sites that keep it alive". 
Based on that warning from Krippendorf (1977) and the conclusion drawn by Chung and collaborators that (2019) "the more conserved a protected area is, the more visitors it attracts", it can be seen that the implantation of the RBT brings with it an inherent challenge to its potential for stimulating a greater flow of people towards the PAs.

In that sense it is worth registering the fact that even the oldest projects like the Appalachian Trail, which was started effectively in 1937, display variations in the degree of conservation of their areas. In the case of that American trail, the areas are best preserved towards the southern end where they are administered by public bodies and in the north where they are in areas of private property, but there are many intermediate stretches with inadequate protection (MCKINLEY et al., 2019).

Therefore, the greatest challenge facing those who support the RBT is to effectively demonstrate its relation with the conservation of Protected Areas. Only when that has been proved beyond doubt will this project be able to convince the skeptics that the hiking activity is much more than a simple walk in the park and can become an important instrument for the management of natural areas.

To that end, monitoring the impacts must be done by the PA administrators to ensure that any eventual harm is rectified and to boost the positive impacts. It must be stressed how important it is to involve the trail users in this process so that they can be warned about the impacts of their influence during visitation and to prohibit any possible damage to the natural resources such as graffiti or harming the fauna and flora.

In that way the trail user's involvement can be converted into "positive action to generate and perfect affective bonds with nature" (MAMEDE et al., 2017) and in so doing, promote the valuing of the PAs. In addition, the users' participation in registering the environmental conditions along the trail they have visited could be an important contribution to environmental conservation.

In that sense, among the good practices that could serve as references for involving visitors in conservation, there is the participative process 'Atlas Mont Blanc' implanted by the Centre de Recherches sur les Écosystèmes d'Altitude (High Altitude Ecosystems Research Center) in the surroundings of the Mont Blanc massif in France. In it the visitor is invited to play an active role in monitoring the fauna and flora (CREA MONT BLANC, 2018). Such environmental monitoring could be combined with an application such as the 'Guardião' App of the Transcarioca Trail which currently enables people to denounce predatory practices via the App installed in their smartphones (TRILHA TRANSCARIOCA, 2018).

\section{Final Considerations}

The prospect of an increase in the demand for open air activities in Brazil due to the accelerated urbanization process and increasing urban densification associated with the need to foster the simple and orderly public use of natural areas, whether they are in PAs or not, makes the creation of the Brazilian Long Trails Network an instrument with extraordinary potential for maintaining and conserving Protected Areas.

The RBT brings with it a new possibility for expanding society's support for the 
conservation of those areas, whether on the part of those users who enjoy a quality experience in nature or on the part of populations of the surrounding areas who are benefited by the increased, orderly, public use of the trails.

Another aspect to be borne in mind is the need for studies of the positive impact on public health stemming from the use of the trails; studies that should involve medium and long term assessments.

The results the RBT has obtained so far have been very favorable but it must be remembered that similar initiatives implanted in other countries have shown that projects of this kind are not without their drawbacks and difficulties that they generate associated to discontinuity or to negative impacts on the conservation of certain species or spaces.

For that reason the recommendation that must be made to all those involved in the implantation of regional trails associated with the RBT is to create monitoring processes to verify whether the trail is effectively collaborating with the achievement of the objectives for which the network was planned.

\section{References}

ARENA, R.; BOND, S.; O’NEIL, R.; LADDU, D. R.; HILLS, A.P.; LAVIE, C.J.; MCNEIL, A.. Public Park Spaces as a Platform to Promote Healthy Living: Introducing a Health Park Concept. Prog Cardiovasc Dis., v. 60, n. 1, p. 152-158, jun./jul. 2017.HealthPark Concept, In: Progress in Cardiovascular Diseases USA, 2017, 20p.

BARDIN, L. Análise de conteúdo. Lisboa: Edições 70, 2000. 225 p.

BENI, M. C; Análise Estrutural do Turismo. São Paulo: Editora SENAC, 2007. 556p.

BOWKER, J.M.; BERGSTROM, J.C.; GILL, J. Estimating the economic value and impacts of recreational trails: a case study of the Virginia Creeper Rail Trail. Tourism Economics, v.13, n. 2, p. 241-260, 2007.

BRASIL. Lei no 9.985 de 18 de julho de 2000. Regulamenta o art. 225, § 1o, incisos I, II, III e VII da Constituição Federal, institui o Sistema Nacional de Unidades de Conservação da Natureza e dá outras providências. Available at: http://www.planalto.gov.br/ccivil_03/LEIS/L9985. htm. Retrieved on: November 15, 2018.

BRASIL. Ministério do Meio Ambiente. Portaria conjunta (MMA/Mtur) no 407, de 26 de março de 2018a. Implementa a Rede Nacional de Trilhas de Longo Curso. Available at: https://www.mma.gov.br/informma/item/15168-governo-federal-lança-rede-de-trilhas-de-longo-percurso.html Retrieved on: February 26, 2020.

BRASIL Ministério do Turismo. Brasil ganha sistema de trilhas de longo curso. 2018b. Available at: http://www.turismo.gov.br/\%C3\%BAltimas-not\%C3\%ADcias/12025-brasil-ganha-sistema-de-trilhas-de-longo-curso.html. Retrieved on: November 15, 2018. 
BRASIL. Manual de Sinalização de Trilhas. Brasília: Instituto Chico Mendes de Conservação da Biodiversidade, 2018c. Available at: http:/www.icmbio.gov.br/portal/images/stories/comunicacao/publicacoes/publicacoes-diversas/manual_de_sinalizacao_de_trilhas_ICMBio_2018.pdf. Retrieved on: 15 nov. 2018.

BRASIL. Ministério do Meio Ambiente. Portaria no 75, de 26 de março de 2018d. Dispõe sobre a instituição do Programa Nacional de Conectividade de Paisagens, no âmbito do Ministério do Meio Ambiente. Available at: http://www.lex.com.br/legis_27630257_PORTARIA_N_75_ DE_26_DE_MARCO_DE_2018.aspx. Retrieved on: 15 nov. 2018.

BREVES, G.; MENEZES, P. C. Entenda o que é o Sistema Brasileiro de Trilhas de Longo Curso. Wikiparques, 4 set. 2018. Available at: https://www.wikiparques.org/entenda-o-que-e-o-sistema-brasileiro-de-trilhas-de-longo-curso/. Retrieved on: 15 nov. 2018.

CAMINHO DAS ARAUCÁRIAS. Trilha do Caminho das Araucárias (Grupo Público, 2018). 2018. Available at: facebook.com/groups/1321470374628111/. Retrieved on: 25 fev. 2019.

CAMINHO DAS ARAUCÁRIAS. Ata de Reunião realizada em 02 de julho 2019. Grupo gestor do Caminho das Araucárias. Cambará do Sul, RS, 2019a.

CAMINHO DAS ARAUCÁRIAS. Mutirão de voluntariado no Caminho das Araucárias. 2019b. Available at: https://www.facebook.com/TrilhaCaminhodasAraucarias/. Retrieved on: 5 set. $2019 \mathrm{~b}$.

CASTRO, E. B. V. de. Changing a Brazilian Protected Areas Paradigm: Why Public Use Is Not Just Optional. Journal of Parks and Recreation Administration, v. 36, p. 129-140, 2018.

CHUNG, M. G.; DIETZ, T.; JIANGUO, L. Global relantionships between biodiversity and nature-based tourism in protected areas. Ecosystem Service, Netherlands, n. 34, p. 11-23, 2018.

COHEN, D. A.; MCKENZIE, T. L.; SEHGAL, A.; WILLAMSON, S.; GOLNELL, D.; LURIE, N. Contribution of Public Parks to Physical Activity. Research and Practice, American Journal of Public Health, v. 97, n. 3, p. 509-514, 2005.

CORREIA, R. A.; JEPSON, P; MALHADO, A. C. M.; LADLEA, R. J. Culturomic assessment of Brazilian protected areas: Exploring a novel index of protected area visibility. Ecological Indicators, Amsterdã, v. 85. p. 165-171, 2018.

CREA MONT BLANC. Atlas Mont Blanc. 2018. Available at: http://www.atlasmontblanc.org/ fr. Retrieved on: 10 dez. 2018.

EAGLES, P. F. J.; MCCOOL, S. F.; HAYNES, C. D. A. Sustainable tourism in protected areas: guidelines for planning and management. Cambridge, UK: IUCN, Gland, 2002. 191 p.

EMPRESA BRASILEIRA DE PESQUISA AGROPECUÁRIA (EMBRAPA). Atribuição de Terras no Brasil. 2018. Available at: https://www.embrapa.br/gite/projetos/atribuicao/170602 WEB_EMBRAPA_ATRIBUICAO_DAS_TERRAS.pdf. Retrieved on: December 10, 2018. 
EUROPEAN RAMBLERS ASSOCIATION (ERA). E-paths. 2018. Available at: http://www. era-ewv-ferp.com/walking-in-europe/e-paths/. Retrieved on: December 10, 2018.

FACEBOOK. Rede Brasileira de Trilhas de Longo Curso. 2018. Available at: https://www. facebook.com/search/top/?q=sistema\%20brasileiro\%20de\%20trilhas. Retrieved on: September 15, 2018.

FÉDÉRATION FRANÇAISE DE LA RANDONNÉE PÉDESTRE (FFRP). Historique. 2017. Available at: https:/www.ffrandonnee.fr/_13/historique.aspx. Retrieved on: December 10,. 2018 .

FIGUEIREDO, A. H. O território Brasileiro. Atlas Digital do Brasil. Brasília: IBGE, 2010. 307p.

FUNDACIÓN SENDERO DE CHILE. Nuestra História. 2018.Available at: https:/www.fundacionsenderodechile.org/historia. Retrieved on: December 10, 2018.

GIL, A. C. Métodos e Técnicas de Pesquisa de Pesquisa Social. 6. ed. São Paulo: Ed. Atlas, 2011. 126p.

INSTITUTO BRASILEIRO DE GEOGRAFIA E ESTATÍSTICA (IBGE). IBGE apresenta nova área territorial brasileira: $8.515 .767,049 \mathrm{~km}^{2}$. 2012. Available at: https://agenciadenoticias.ibge.gov.br/agencia-sala-de-imprensa/2013-agencia-de-noticias/releases/14318-asi-ibge-apresenta-nova-area-territorial-brasileira-8515767049-km. Retrieved on: December 10,. 2018.

INSTITUTO CHICO MENDES DE CONSERVAÇÃO DA BIODIVERSIDADE (ICMBIO). Brasil ganha rede de trilhas de longo curso. Biodiversidade Brasileira, Brasília, n. 6, [s. p.], 19 out. 2018.

INSTITUTO CHICO MENDES DE CONSERVAÇÃO DA BIODIVERSIDADE (ICMBIO). Número de visitantes nas UC no Brasil: Painel Dinâmico, 2019a.

INSTITUTO CHICO MENDES DE CONSERVAÇÃO DA BIODIVERSIDADE (ICMBIO). Programa de Voluntariado no PNSJ. ICMBio em Foco, Brasília, ano 11, n. 502, p. 12, 2019b.

INSTITUT NATIONAL DE LA STATISTIQUE ET DES ÉTUDES ÉCONOMIQUES (INSEE). Comparateur du Territoire. 2018. Available at: https://www.insee.fr/fr/statistiques/14055 99? geo =FRANCE-1. Retrieved on: December 10, 2018.

JEPSON, P. R.; CALDECOTT, B.; SCHMITT, S. F.; CARVALHO, S. H.C. Protected area asset stewardship. Biological Conservation, n. 212, p. 183-190, 2017.

KASTENHOLZ, E.; RODRIGUES, Á. Hiking as a Recreational and Tourist Activity - Comparing Portuguese Hikers with those from other Nationalities. Revista Turismo $\mathbb{\&}$ Desenvolvimento, Campinas, n. 7/8, p. 83-91, 2007.

KRIPPENDORF, J. Les Devoreus de Payasages: Le Tourisme Doit-Il Detruire les Sites Qui Le Font Vivre? Lausanne: Ed. 24 Heures, 1977. 157p. 
LABORATOIRE SUR LES VULNÉRABILITÉS ET LINNOVATION DANS LE SPORT (L-VIS); FRANCE. PÔLE RESSOURCES NATIONAL SPORTS DE NATURE (PRNSN); FÉDÉRATION PROFESSIONNELLE DES ENTREPRISES DU SPORT ET DES LOISIRS (FPS); FÉDÉRATION FRANÇAISE DES INDUSTRIES SPORT ET LOISIRS (FIFAS). Baromètre des sports et loisirs de nature en France. Lyon, France: Université Claude Bernard, Lyon 1, 2016.

GALLEGOS, A. G. The physical - sports activities in the nature and the tourist industry. Revista Internacional de Medicina y Ciencias de la Actividad Física y elDeporte, v. 7, n. 26, p. 111 $127,2007$.

LOBODA, C. R.; DEANGELIS, B. L. D. Áreas verdes públicas urbanas: conceitos, usos e funções. Ambiência, Guarapuava, v. 1, n. 1, p. 125-139, 2005.

MACIEL, L.; BITENCOURT, M. D.; SILES, M. F. R. Alterations in the herbaceous vegetation along a tourist trail in the Serra do Mar, São Paulo, Brazil. Acta Bottanica Brasilica, Rio de Janeiro, n. 25, p. 628-632, 2011.

MAMEDE, S.; BENITES, M.; SABINO, J.; ALHO, C. J. R. Ecoturismo na região turística Caminho dos Ipês: conexões entre identidade biofílica e usufruto dos serviços ecossistêmicos. Revista Brasileira de Ecoturismo, São Paulo, v. 10, n. 4, p. 938-957, 2017.

MATOS, R.; BAENINGER, R. Migração e urbanização no Brasil: processos de concentração e desconcentração espacial e o debate recente. Cadernos do Leste, Belo Horizonte, v. 8, p. 342384, 2004.

MCKINLEY, P. S.; BELOTE, R. T.; APLET, G. H. An assessment of ecological values and conservation gaps in protection beyond the corridor of the Appalachian Trail. Conservation Science and Practice, v. 1, n. 6, p. 1-13, jun. 2019.

MEDEIROS, R.; YOUNG; C. E. F.; PAVESE, H. B.; ARAÚJO, F. F. S. Contribuição das unidades de conservação brasileiras para a economia nacional: Sumário Executivo. Brasília: UNEP-WCMC, 2011. 44p.

MENEGASSI, D. Um caminho pelos significados da palavra socioambiental na Floresta Amazônica. 2017a. Available at: https:/www.oeco.org.br/reportagens/um-caminho-pelos-significados-da-palavra-socioambiental-na-floresta-amazonica/. Retrieved on: 4 mar. 2019.

MENEGASSI, D. Projeto de trilhas de longo curso brasileiras começa a sair do papel. 2017b. Available at: https://www.oeco.org.br/reportagens/projeto-de-trilhas-de-logo-curso-brasileiras-comeca-a-sair-do-papel/. Retrieved on: December 10, 2018.

MENEGASSI, D. Ecoturismo é destaque na 1aㅡ edição do Prêmio Nacional do Turismo. 2018. Available at: https:/www.oeco.org.br/reportagens/ecoturismo-e-destaque-na-1a-edicao-do-premio-nacional-do-turismo/. Retrieved on: September 10, 2019.

MENEGASSI, D. Mutirão inicia sinalização da Trilha Transmantiqueira . 2019. Available 
at: https://www.wikiparques.org/mutirao-inicia-sinalizacao-da-trilha-transmantiqueira/. Retrieved on: March 4, 2019.

MENEZES, P. C. Sinalização de Trilhas - Guia Prático. 2014. Available at http://sinalizetrilhas.wikiparques.org.br/download/. Retrieved on: November 15, 2018.

MENEZES, P. C. Trilha Transcarioca, um trabalho de muitos. 2015. Available at https:// www.oeco.org.br/colunas/pedro-da-cunha-e-menezes/29138-trilha-transcarioca-um-trabalho-de-muitos/. Retrieved on: November 15, 2018.

MENEZES. P. C. O Brasil no caminho das trilhas de longo curso. 2017. Available at: https:// www.oeco.org.br/colunas/pedro-da-cunha-e-menezes/o-brasil-no-caminho-das-trilhas-de-longo-curso/. November: 15, 2018.

MERRIAM, D.; BALITY, A.; STEIN, J.; BOEHMER, T. Improving Public Health through Public Parks and Trails: Eight Common Measures. Summary report. Washington, DC, USA: US Department of Health and Human Services, Centers for Disease Control and Prevention and US Department of the Interior, National Park Service, 2017. 26 p.

NATIONAL PARK SERVICE (NPS). Estatísticas do NPS. Estatísticas de Uso de Visitantes do Serviço Nacional de Parques. Available at: https://irma.nps.gov/Stats/Reports/Park/. Retrieved on: January 29, 2019.

O GLOBO. Trilha Transcarioca torna-se legalmente a maior trilha urbana da América Latina. 2017. Available at: https://oglobo.globo.com/rio/bairros/trilha-transcarioca-torna-se-legalmente-maior-trilha-urbana-da-america-latina-21479504. Retrieved on: 15 nov. 2018.

PENNSYLVANNIA LAND TRUST ASSOCIATION (PLTA). Economic Benefits of Trail. 2011. Available at: https://conservationtools.org/guides/97-economic-benefits-of-trails. Retrieved on: December 10, 2018.

PLOG, S. C. The Power of Psychographics and the Concept of Venturesomeness. Journal of Travel Research, La Trobe University, Austrália, v. 40, p. 244-251, 2002.

REDE BRASILEIRA DE TRILHAS (RBT). Rede Brasileira de Trilhas - Dados atualizados. 2019. Available at:

https:/www.facebook.com/notes/rede-brasileira-de-trilhas/rede-brasileira-de-trilhas-entra-na-era-digital/803684486694103/. Retrieved on: September 5, 2019.

RIBEIRO JÚNIOR, C. E. Trilha Velho Chico: por caatingas e cerrados até a Canastra (2018). Available at: https://www.oeco.org.br/colunas/colunistas-convidados/trilha-velho-chico-por-caatingas-e-cerrados-ate-a-canastra/. Retrieved on: March 4, 2019.

RUSCHMANN, D. Turismo e planejamento sustentável: a proteção do meio ambiente. Campinas: Ed. Papirus, 1997. 300 p. 
SÃO PAULO (Estado). Secretaria de Estado do Meio Ambiente (SEMA). Passaporte para as trilhas de São Paulo. 2. ed. São Paulo: Secretaria de Estado do Meio Ambiente, 2018. 80p.

SOULLARD; D.F. Impacts of Recreational Trails on Wildlife Species: Implications for Gatineau Park. Master of Science in Environmental Sustainability (Dissertation). University of Ottawa: Institute of the Environment, Otrawa, Canadá, 2017. 67p.

SOUZA, T. V. S. B.; SIMÕES, H. B. Contribuições do Turismo em Unidades de Conservação Federais para a Economia Brasileira. Brasília: ICMBio/MMA, 2018. 28 p.

STATCOUNTER GLOBAL STATS. Search Engine Market Share Brazil. 2019. Available at: http://gs.statcounter.com/search-engine-market-share/all/brazil. Retrieved on: February 25, 2019.

STATISTA. Direct economic contribution of national park visitor spending in the United States from 2012 to 2017 (in billion U.S. dollars). 2018. Available at: https://www.statista. com/statistics/220984/significance-of-spending-in-us-national-park-regions/. Retrieved on: November 15, 2018.

TRILHA TRANSCARIOCA. Trechos. 2018. Available at: https://rilhatranscarioca.com.br/ os-trechos/. Retrieved on: November 15, 2018.

VALLON PONT D'ARC. Évaluation des retombées économiques et sociales de la Rando des Jasseries. Collectif. Vallon Pont d'Arc: Pôle ressources national sports de nature, 2016. Available at: http://www.sportsdenature.gouv.fr/publications/evaluation-des-retombees-economiques-et-sociales-de-la-rando-des-jasseries. Retrieved on: November 15, 2018.

XIE, Z. Assessment of Trail Characteristics and Invasive Species Prevalence of an Alternative Border Crossing Route for the A2A Trail. 2018. 72 f. Graduate Program in Environmental Studies (MSc in Environment - Queen's University, Ontario, Canada, 2018. Available at: https://qspace.library.queensu.ca/handle/1974/24247. Retrieved on: November 15, 2018.

YOUTUBE. Transcarioca e o Sistema Brasileiro de Trilhas de Longo Curso. 21 ago. 2018. 11 posts. Available at: https://www.youtube.com/playlist?list=PLTflb_xLlBPggvS4J1wRhtre1FUosdlAT. Retrieved on: January 15, 2019.

WIKILOC. Caminho das Araucárias. 2019. Available at: https://pt.wikiloc.com/trilhas-trekking/caminho-das-araucarias-28863487 Retrieved on: September 20, 2019.

WORLD TRAVEL \& TOURISM COUNCIL (WTTC). Travel \& Tourism Economic Impact 2018 - Brazil. 2018. Available at: https://www.wttc.org/-/media/files/reports/economic-impact-research/cities-2018/city-travel--tourism-impact-2018final.pdf. Retrieved on: December 10, 2018. 
Michel Tadeu Rodrigues Nolasco de Omena

$\square$ michel.omena@gmail.com

ORCiD: https://orcid.org/0000-0001-9475-2294
Submitted on: 30/03/2019

Accepted on: 15/04/2020 2020;23:e00532

\section{Michel Bregolin}

ఐmbregolin@ucs.br

ORCiD: https://orcid.org/0000-0002-4050-7557

How to cite: OMENA, M. T. R. N., BREGOLIN,. The Importance of Regional Trails for the Viability of the Brazilian Long Trails Network. Ambiente $\mathbb{\&}$ Sociedade. São Paulo, v. 23, p. 1-21, 2020. 


\title{
A Importância das Trilhas Regionais para Viabilização da Rede Brasileira de Trilhas de Longo Curso
}

\author{
Michel Tadeu R. N. de Omena \\ Michel Bregolin
}

São Paulo. Vol. 23, 2020

Artigo Original

\begin{abstract}
Resumo: A urbanização acelerada tem incentivado o turismo em ambientes naturais e a busca da reconexão homem-natureza. Nesse contexto, este artigo relata a implantação da Rede Brasileira de Trilhas (RBT) a partir do acompanhamento das atividades da Trilha Regional "Caminho das Araucárias", da análise de documentos oficiais e dados sobre a RBT presentes em mídias digitais. Avaliamos o potencial de a RBT contribuir para a conservação da natureza, a conexão de paisagens, a promoção do turismo e do bem-estar via recreação ao ar livre. Neste estudo constatamos que foram criados 1.600 novos quilômetros de trilhas em dois anos e que houve o crescimento do voluntariado e da integração entre gestores de Unidades de Conservação (UCs). Por fim, ressalta-se a importância das trilhas regionais para viabilizar a RBT, destacando a sua relevância para a conservação das UCs e a geração de emprego e renda local conforme apontam iniciativas internacionais semelhantes.
\end{abstract}

Palavras-chave: Trilhas; Conservação, Turismo; Áreas Protegidas, Rede Brasileira de Trilhas, Caminho das Araucárias.

Como citar: OMENA, M. T. R. N., BREGOLIN, M. A Importância das trilhas regionais para viabilização da rede brasileira de trilhas de longo curso. Ambiente \& Sociedade. São Paulo, v. 23, p. 1-21, 2020.

DOI: http://dx.doi.org/10.1590/1809-4422asoc20190053r2vu2020L5AO 


\title{
La Importancia de los Senderos Regionales para la Viabilidad de la Red Brasileña de Senderos Largos
}

\author{
Michel Tadeu R. N. de Omena \\ Michel Bregolin
}

São Paulo. Vol. 23, 2020

Artículo original
Resumen: La urbanización acelerada ha alentado el turismo en áreas naturales y la búsqueda de la reconexión hombre-naturaleza. En este contexto, este artículo informa sobre la implementación de la Red Brasileña de Senderos a partir del seguimiento de las actividades del Sendero Regional "Camino de las Araucarias", el análisis de documentos oficiales y datos sobre la Red disponibles en diferentes medios digitales. Evaluamos el potencial para contribuir a la conservación de la naturaleza, la conexión del paisaje, la promoción del turismo y el bienestar humano. Encontramos en este estudio 1.600 kilómetros de senderos creados en dos años, además del crecimiento del voluntariado y de la integración entre los administradores de las áreas protegidas. Concluimos por la importancia de los senderos regionales, destacando su relevancia para la conservación de las áreas y la generación de empleo e ingresos locales, basados en las buenas prácticas de iniciativas internacionales similares.

Palabras-clave: Senderos; Conservación; Turismo; Áreas Protegidas; Sistema de Senderos Brasileños; Camino Araucárias.

Como citar: OMENA, M. T. R. N., BREGOLIN, M. La Importancia de los Senderos Regionales para la Viabilidad de la Red Brasileña de Senderos Largos. Ambiente \& Sociedade. São Paulo, v. 23, p. 1-21, 2020.

DOI: http://dx.doi.org/10.1590/1809-4422asoc20190053r2vu2020L5AO 